\title{
Decolonisation and Teaching Law in Africa with Special Reference to Living Customary Law
}

\author{
C Himonga and F Diallo *
}

\section{P.E.R}

Pioneer in peer-reviewed, open access online law publications

Author

Chuma Himonga and

Fatimata Diallo

Affiliation

University of Cape Town South Africa

Email chuma.himonga@uct.ac.za and diallofatimaster@gmail.com

Date published

26 October 2017

Editor Prof P du Plessis

How to cite this article

Himonga $\mathrm{C}$ and Diallo $\mathrm{F}$

"Decolonisation and Teaching Law in Africa with Special Reference to Living Customary Law" PER / PELJ 2017(20) - DOI

http://dx.doi.org/10.17159/1727-

3781/2017/v20i0a3267

Copyright

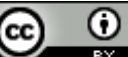

DOI

http://dx.doi.org/10.17159/17273781/2017/v20i0a3267

\begin{abstract}
The student protests in South African Universities, which started in 2015, demanded the decolonisation of certain aspects of higher education. While the primary demand is free education, issues of the curriculum and transformation connected with the country's history of colonialism and apartheid have also surfaced. In the field of law, demands for curriculum change are accompanied by the broad issue of the decolonisation of law, translating into questions of legal history, the concept of law, the role of law in African societies, the status of indigenous systems of law in the post-independent/apartheid legal system, and how law is taught in law schools.
\end{abstract}

This paper examines the idea of the decolonisation of law in relation to the teaching of law in African states previously under the influence of English or Roman-Dutch colonial/apartheid legal history. The teaching of law is with special reference to the system of law that governs the majority of people in Africa in private law and aspects of governance - living customary law. The paper examines the design of legal education with respect to three elements that are essential to the decolonisation of law and legal education. The elements under review are the inclusion of living customary law in legal education, a shift in the legal theoretical paradigm within which law is taught, and the interdisciplinary study of law. Thus, the paper links the decolonisation of law to how law is taught, with special reference to living customary law. In discussing these elements, the paper draws examples from the South African legal system, because it has the most advanced jurisprudential conceptualisation of customary law on the African Continent.

\section{Keywords}

Decolonisation of law; legal theory; teaching law; living customary law; interdisciplinary. 


\section{Introduction}

In 2015 South African universities witnessed a spate of protests under the banners of "Rhodes Must Fall" and "Fees Must Fall" and the broad issues of social justice and the transformation of universities from their colonial and Eurocentric heritages. These protests are likely to change the nature of tertiary institutions and teaching in these institutions in South Africa. ${ }^{1}$ With regard to legal studies, the protests included demands for changes in the curricula in law schools. In my view, implicit in this demand is a call for a rethinking of broader legal issues, such as the decolonisation of law, which in turn raises questions about the legal history of African countries; the concept of law; the role of law in African societies; the status of indigenous systems of law in post-independence or post-apartheid legal systems; and how law is taught in African law schools. This proposition is partially confirmed by the views of some law students. Alex Hotz, for example, wrote: "As a law student, I believe decolonising the law faculty goes beyond the faculty and the institution. It speaks to what the law is and how it is used within society." 2 These demands have therefore kindled the need to reflect on these issues from different perspectives.

The aim of this paper is to explore the idea of decolonisation and the teaching of law in African institutions of higher learning. It focuses on the teaching of law in a decolonised African context, with special reference to living customary law. The paper argues that the redesigning of the teaching of law - involving three elements - is critical to the decolonisation of law in Africa. The three elements are the inclusion of living customary law in legal education, a paradigm shift in legal theory, and the interdisciplinary study of law. Underpinning this argument are three important premises. The first premise is that decolonisation cannot be achieved without the development

\footnotetext{
* Chuma Himonga. LLB (University of Zambia). LLM PhD (University of London). Professor of Law in the Department of Private Law, University of Cape Town Law Faculty; holder of the DST/NRF SARChI Chair in Customary Law, Indigenous Values and Human Rights, University of Cape Town. Email: chuma.himonga@uct.ac.za. We acknowledge Professor Han Van Dijk for his contribution on ideas about decolonisation and interdisciplinary studies which we developed together in the proposal on the concept and structure of an Institute for Interdisciplinary Studies of Law in Africa (hereafter referred to as the IISLA proposal) submitted to the University of Cape Town by the DST/NRF SARChI Chair in Customary Law, Indigenous Values and Human Rights at the University of Cape Town in 2015.

** Dr Fatimata Diallo. Bachelor in Public Law, Professional Masters, M.Phil (University Gaston Berger and Francophone University Association), PhD (Leiden University). Formerly Senior Research Fellow at the DST/NRF SARChI Chair in Customary Law, Indigenous Values and Human Rights at the University of Cape Town. Email: diallofatimaster@gmail.com.

1 Although we refer to 2015 as the year in which the protests started, the protests continued in 2016.

2 See UCT 2015 Year in Review 23.
} 
of indigenous systems of law through legal education. In essence, the development and survival of living customary law cannot be divorced from the decolonisation of law in Africa.

The second premise is that living customary law as a concept of law represents a move away from the colonial (and apartheid) heritage of the distortion of customary law. This makes this system of law the appropriate basis for, and object of, decolonisation of law in comparison with its counterpart, official customary law. The third premise is that living customary law has a distinctive character of its own, which requires special consideration for the purposes of teaching law in a decolonised context.

In advancing the argument of this paper, we draw examples from the South African legal system because, on the African continent, it has the most advanced jurisprudential conceptualisation of customary law as both living customary law and official customary law.

The argument of the paper is advanced in five sections. Following this introduction, the second section is a brief general background to the legality of protest action in tertiary institutions within the framework of the Constitution of South Africa. This section is intended to show that for the most part students were within their right to protest. The third section sets out the conceptual frameworks of decolonisation and customary law. The fourth section delves into the three elements of decolonisation - the teaching of living customary law, the theoretical paradigm within which law is taught, and interdisciplinary studies. The fifth section concludes the paper.

\section{The legal status of protest action in tertiary institutions}

The Supreme Court of Appeal pronounced itself on the legal status of protest action within the constitutional framework of South Africa in Hotz $v$ $U C T .{ }^{3}$ This was an appeal from the High Court decision granting an interdict to the University of Cape Town barring five participants in one of the protest actions on the campus from entering the premises of the University because they had allegedly committed unlawful acts in the course of their protest.

The Court held, inter alia, ${ }^{4}$ that protest action is not itself unlawful and that the right to protest against injustice is protected by the Constitution, "not only specifically in section 17 , by way of the right to assemble, demonstrate and present petitions, but also by other constitutionally protected rights, such as the right of freedom of opinion (s15(1)); the right of freedom of

Hotz v University of Cape Town 20172 SA 485 (SCA).

Hotz v University of Cape Town 20172 SA 485 (SCA) paras 62-63. 
expression (s16(1)); the right of freedom of association (s18) and the right to make political choices and campaign for a political cause $(\mathrm{s} 19(1)))^{\prime .}{ }^{5}$ However, the Court qualified these rights by holding that the mode of exercise of those rights is also the subject of constitutional regulation, that is: (a) the right to freedom of speech does not extend to the advocacy of hatred that is based on race or ethnicity and that constitutes incitement to cause harm (section 16(2)(c)); (b) the right to demonstrate is to be exercised peacefully and unarmed (section 17); and (c) all rights are to be exercised in a manner that respects and protects the foundational value of the human dignity of other people (section 10) and the rights other people enjoy under the Constitution. Citing its own decisions in other cases, the Court stated: ${ }^{6}$

\begin{abstract}
Our Constitution saw South Africa making a clean break with the past. The Constitution is focused on ensuring human dignity, the achievement of equality and the advancement of human rights and freedoms. It is calculated to ensure accountability, responsiveness and openness. Public demonstrations and marches are a regular feature of present day South Africa. I accept that assemblies, pickets, marches and demonstrations are an essential feature of a democratic society and that they are essential instruments of dialogue in society. The [Regulation of Gatherings] Act was designed to ensure that public protests and demonstrations are confined within legally recognised limits with due regard for the rights of others.
\end{abstract}

From this decision it may be inferred that protests in tertiary institutions are not to be treated any differently from other types of protest action in the country. Thus, although the actions of the appellants were restricted by an interdict, the right to lawful protest itself was unquestionable.

This paper deals with protests within the scope of the law set out above. It is an attempt to discuss decolonisation under what Davis has called "an imperative to engage as to how tertiary institutions respond to locality and context". ${ }^{7}$

\title{
3 The conceptual frameworks: decolonisation, living customary law and official customary law
}

The definition of decolonisation is unsettled, if not contested. It is therefore important in a paper such as this one, which explores the idea of teaching law in a decolonised context, to proffer a definition within the limited scope

Hotz v University of Cape Town 20172 SA 485 (SCA) paras 62-63.

SATAWU v Garvis 20131 SA 83 (CC) para 68.

See Davis 2016 http://www.groundup.org.za/article/academics-and-fallistmovement/. 
of the teaching of law. This concept is discussed in this section along with the concepts of living customary law and official customary law.

\title{
3.1 Decolonisation
}

In this section we attempt to provide a definition of decolonisation that is relevant to the teaching of law in an African context.

In their joint reflection on decolonising the University of Cape Town, Max Price and Russel Ally stated that "decolonisation ... should certainly not be reduced to some naïve ... desire to return to a pristine, unblemished Africa before the arrival of the settlers". ${ }^{8}$ We agree with this statement because it seems to allude to a non-romanticised and non-rhetorical concept of decolonisation, on the one hand, and a dynamic meaning of decolonisation, on the other hand. Elsewhere we define decolonisation in a legal context as follows:

\begin{abstract}
[W]hile indigenous approaches should, in our view, be central to the decolonisation of law, this is not a call for the unconditional indigenisation of law in which an anti-colonial discourse, which is frequently trapped within the same colonial epistemology, is advanced uncritically. Instead, we suggest that a more meaningful point of departure in the decolonisation of law is the defining of law from a "non-colonial" position and from alternative legal epistemologies. In this respect, decolonisation draws from different sources of law and normative agencies to promote the transformative potential of law in achieving more social and economic justice. ${ }^{9}$
\end{abstract}

Decolonisation is, furthermore, a move from a hegemonic or Eurocentric conception of law connected to legal cultures historically rooted in colonialism (and apartheid) in Africa to more inclusive legal cultures. ${ }^{10}$

We extend this notion of decolonisation to this paper. Additionally, decolonisation refers to locating the paradigmatic and theoretical shifts that are required for the teaching of law.

\subsection{Official customary law and living customary law}

Official customary law refers to a variety of sources of state law. In some countries, such as South Africa, official customary law may be divided into two categories for the purposes of this paper. The first category, the old order category, consists of codifications of customary law, such as the Zulu and Natal codes of customary law; legislation purporting to embody

$8 \quad$ UCT 2015 Year in Review 23.

9 This definition is derived from the IISLA proposal 4. See also Himonga (forthcoming 2017) Acta Juridica.

10 Himonga (forthcoming 2017) Acta Juridica. 
customary law, such as the Black Administration Act: ${ }^{11}$ court precedents or case law; and textbooks whose content is based on legislation and court precedents or other state law sources of customary law. One or other kind of source in this category exists in most, if not all, former British colonies in Africa.

The second category of official customary law, the new order official customary law, consists of legislation arising from the provisions of the Constitution that recognise customary law. For example, section 15 of the South African Constitution states that legislation may be enacted to recognise traditional forms of marriage or marriages concluded according to custom. Section 211(3) of the same Constitution provides that the courts must apply customary law subject to, among other things, legislation dealing specifically with customary law. In 1998, the Recognition of Customary Marriages Act was enacted to reform the customary law of marriage in line with the South African Constitution, including the constitutional provisions on gender equality. This Act makes provision for the application of both customary law and the common law. ${ }^{12}$ It is therefore a hybrid form of official customary law linked to new efforts aimed at transforming indigenous institutions within African constitutional frameworks. ${ }^{13}$

Although both the old order and new order categories of official customary law bear the appellation of customary law, they often bear little resemblance to the living customary law regulating the day-to-day lives of people on the ground. ${ }^{14}$ Most importantly, the old order category of official customary law bears the marks of colonialism (and apartheid). This is because it was designed to advance colonial or apartheid state interests, ${ }^{15}$ in the process of which it was distorted. For these reasons, the inclusion of old order official customary law in legal education would perpetuate the colonial legal legacy, which is contrary to the idea of decolonisation. Therefore, this category of official customary law should not form a core part of the legal curriculum. In contrast, the new order official customary law should be included in legal education, because it forms part of the constitutionalisation of customary

$11 \quad$ Black Administration Act 38 of 1927. This Act regulated several aspects of the lives of Black South Africans during the apartheid era, but it has now been largely repealed with the exception of a few provisions regulating the chiefs' and headmen's courts.

12 For the purposes of this paper, the term "common law" is used in a broad sense to represent the body of law in Africa which arose from Eurocentric sources due to colonialism. No distinction is drawn between the families of legal systems, such as common law, civil law and mixed legal systems. The Reform of the Customary Law of Succession and Regulation of Related Matters Act 11 of 2009, which came into operation on 20 September 2009, also falls in this category of official customary law.

14 See generally Himonga and Moore Reform of Customary Marriage. See generally Chanock Law, Custom and Social Order. 
law, along with living customary law, which is the focus of this paper as elaborated in the next section, where the concept of living customary law receives further consideration.

\section{Designing legal education for decolonisation}

Arguably, three elements are essential for decolonising law and legal education. These are the inclusion of living customary law in legal education, a shift in theoretical paradigm within which law is taught and the interdisciplinary study of law. A discussion of each of these elements follows.

\subsection{The inclusion of living customary law in legal education}

As intimated in the discussion of the conceptual framework above, living customary law is the law that governs the legal relations of people who are subject to a given system of customary law in their day-to-day life. An equally fitting definition is that adopted by South African legislation: "the customs and usages traditionally observed among the indigenous African peoples of South Africa which form part of the culture of those people". ${ }^{16}$ The use of the term "culture" in this definition is significant, as it seems to allude to the dynamic nature of living customary law - as culture is dynamic, so is living customary law. Living customary law represents the practices or customs observed and invested with binding authority by the people whose customary law is under consideration. ${ }^{17}$

Thus, living customary law is the law observed by, or rooted in, each ethnic group of Africa regardless of whether it is recognised by the state. As an unwritten store of legal ideas and knowledge, living customary law is passed down from one generation to the next orally. This store of knowledge is uniquely African in the sense that though not insulated from global conditions, its evolution is shaped within changing African social, economic and political contexts. Moreover, because of its oral nature and flexibility, living customary law can readily and easily be adjusted ${ }^{18}$ to meet the varied needs of justice in a decolonised context.

That living customary law is distinct from other legal systems comprising African legal systems is clear from both academic literature and post-

16 Section 1 of the Recognition of Customary Marriages Act 120 of 1998 and of the Reform of Customary Law of Succession and Regulation of Related Matters Act 11 of 2009.

17 See further Hund 1998 ARSP 420-429.

18 Odgaard and Weis Benton 1998 EJDR 105. 
apartheid jurisprudence in South Africa. In this respect, Bennett has observed:

$[R]$ ules of an oral regime are porous and malleable. Because they have no clear definition, it is difficult to differentiate one rule from another, and, in consequence, to classify rules according to type. If rules cannot be classified, they cannot be arranged into a system, and without the discipline of a system, rules may overlap and contradict one another. In fact strictly speaking, the oral versions of customary law should not be called systems at all. They are probably better described as repertoires, from which the discerning judge may select whichever rule best suits the needs of the case. ${ }^{19}$

What emerges from this statement is a distinctive legal tradition whose logic and methodology does not place primary value on organisation or systemisation, and does not aspire to be a rigid framework of regulation, like other systems such as official customary law or the common law.

Similarly, the Constitutional Court of South Africa implicitly describes living customary $\operatorname{law}^{20}$ as a distinctive and original source of law. Referring to the recognition of customary law by sections 211 and $39(2)^{21}$ of the Constitution, the Court stated: "The Constitution thus 'acknowledges the originality and distinctiveness of indigenous law as an independent source of norms within the legal system...'."22

Arguably, the source of living customary law (ie the people subject to customary law), the value of its flexibility and adaptability as an evolving oral system, and its recognition as a distinctive and original source of indigenous law are all positive elements in the decolonisation of law. These attributes

19 See Bennett Customary Law fn 6, p 3.

In several cases, this court has recognised living customary law as a legitimate form of customary law in the post-apartheid legal system. See for example, the cases listed in note 22 below.

21 Section 211 of Constitution of the Republic of South Africa, 1996 states that: "(1) The institution, status and role of traditional leadership, according to customary law, are recognised subject to the Constitution. (2) A traditional authority that observes a system of customary law may function subject to any applicable legislation and customs, which includes amendments to, or repeal of, that legislation or those customs. (3) The courts must apply customary law when that law is applicable, subject to the Constitution and any legislation that specifically deals with customary law"; section 39(2) provides that "When interpreting any legislation, and when developing the common law or customary law, every court, tribunal or forum must promote the spirit, purport and objects of the Bill of Rights".

See Mayelane $v$ Ngwenyama 20134 SA 415 (CC). The quotation within this quotation is from another decision of the Constitutional Court, Alexkor Ltd $v$ Richtersveld Community 20045 SA 460 (CC) para 51. Also see Bhe v Magistrate, Khayelitsha (Commission for Gender Equality as Amicus Curiae); Shibi v Sithole; South African Human Rights Commission v President of the Republic of South Africa 20051 SA 580 (CC) para 41; Ex parte Chairperson of the Constitutional Assembly: In re Certification of the Constitution of the Republic of South Africa, 199619964 SA 744 (CC) para 197. 
also qualify this system of law for inclusion as a core subject of study in a decolonised system of legal education. Moreover, these qualities of living customary law justify its development and retention in a decolonised legal system, also bearing in mind the fact that this system of law regulates the lives of the majority of the population in African legal systems.

Put differently, living customary law must be taught in all law faculties or law schools and at appropriate levels of the law degree that enable students to comprehend the significance and complexity of the subject within the constitutional frameworks of African countries. Future lawyers and judges need to have an understanding of important aspects of this customary law, including its conceptualisation, its methodology in a broad sense, ${ }^{23}$ and its development as a system of law within African constitutional frameworks. If future lawyers and judges are not given appropriate legal training about living customary law, they will not have the right lens ${ }^{24}$ through which to view customary law - in its own right and not from the perspective of other legal systems. The relevant pronouncements of the South African Constitutional Court above will therefore be devoid of any practical significance.

The link between legal education and the development of a legal system is evident from the pronouncements of South African scholars about the development of Roman-Dutch law (RDL). In the words of Cowen, who we believe is one of the founders of legal education in South Africa, "taught law is tough law". With reference to the survival of RDL against the encroaching influence of English common law he stated:

\begin{abstract}
No legal system can survive unless it is taught scientifically ... taught law is tough law by which [is meant] durable law. In short, the tide could not really turn in favour of the Roman-Dutch law in South Africa [in the nineteenth century] until a sound local tradition of tuition in its basic principles was built up ... if I were asked to single out the cause which, more than any others, set back the prospects of the Roman-Dutch law in South Africa during much of the nineteenth century, I would point to the lack of scientific training in RomanDutch law. ${ }^{25}$
\end{abstract}

According to this statement, legal education was seen as the antidote to the eminent death of RDL due to the influence of other legal traditions or cultures. In our view, this statement is no less true of the survival of living

For example, including case by case approaches and reconciliation as the goal of dispute resolution.

$24 \quad$ Alexkor Ltd v Richtersveld Community 20045 SA 460 (CC) para 51 where it stated: "While in the past indigenous law was seen through the common law lens, it must now be seen as an integral part of our law. Like all law it depends for its ultimate force and validity on the Constitution. Its validity must now be determined by reference not to common law, but to the Constitution." 
customary law or any other indigenous system of law against the influence of imported, yet dominant colonial and apartheid legal systems. Unless customary law is taught in law faculties it will die.

Furthermore, a host of issues concerning living customary law demand the attention of scientific thought in institutions of higher learning if this system is to develop into a modern African legal system. These issues include: (a) the long-standing challenge of how to ascertain living customary law, with the attendant question of how to ensure a measure of certainty about the rules of this system in the context of judicial decision-making; (b) the manipulation and distortion of living customary law, especially in the context of power relations among different sections of the community living under customary law and because of its evolving and oral nature; ${ }^{26}$ (c) appropriate methods of aligning this system of law with constitutional principles and international and regional human rights; (d) the endurance and social legitimacy of living customary law;27 and (e) issues of the universal application of human rights vis a vis cultural rights; and (f) whether and how the fundamentally different world views represented by the living customary law and common law can be merged and reconciled in one body of law - for example, that body of law which has to regulate commerce. We submit that there is no better place for addressing these issues, or for the development of customary law in relation to these issues, than in the academy, in legal education.

In sum, we argue that the teaching of living customary law as part of the core curriculum of legal education is essential to the process of the decolonisation of law, as well as the decolonisation of legal education itself. In the next section we consider the importance of the legal theoretical paradigm within which law is taught to this process.

26 See Chanock Law, Custom and Social Order 81; Kameri-Mbote, Odote and NyamuMusembi Ours by Right 50. In Bhe $v$ Magistrate, Khayelitsha (Commission for Gender Equality as Amicus Curiae); Shibi v Sithole; South African Human Rights Commission v President of the Republic of South Africa 20051 SA 580 (CC) para 154 , the minority judgment of Ngcobo $\mathrm{J}$ identified the issue of distortion of living customary law associated with this law's evolving and oral nature in the following terms: "The evolving nature of indigenous law and the fact that it is unwritten have resulted in the difficulty of ascertaining the true indigenous law as practiced in the community. .... What is more, abuses of indigenous law are at times construed as a true reflection of indigenous law, and these abuses tend to and undermine its value. The difficulty is one of identifying the living indigenous law and separating it from its distorted version."

27 See, for example, Kane, Oloka-Onyango and Tejan-Cole 2005 http://siteresources.worldbank.org/INTRANETSOCIALDEVELOPMENT/Resources /reassessingcustomary.pdf. 


\subsection{The legal theoretical framework}

The predominant legal theoretical framework within which law is taught, at least in law schools under the historical influence of English and RomanDutch common law is legal centralism and positivism. This theory prepares future lawyers and judges to engage with western-type legal systems and legal cultures and not with non-western African legal systems, let alone oral legal traditions. For example, an important aspect of legal positivism is formalism. This strand of legal theory separates legal rules from "nonlegal normative considerations of morality or political philosophy" 28 and requires judges to apply the rules to the facts of the case before them deductively, with the value of legal certainty as a goal, among other things. ${ }^{29}$ However, the rules of living customary law cannot be abstracted from their social contexts. They are embedded in the social realities within which people live their lives. In addition, the values of certainty, stability and predictability which are core to western legal cultures - are not necessarily the primary goals of dispute resolution in living customary law. ${ }^{30}$

It is therefore arguable that the legal education of judges and lawyers in Africa exclusively within the theoretical frameworks of legal positivism and centralism do not adequately prepare them to deal with the application of non-western legal orders, such as living customary law, in which law and its values are viewed differently. The result is that lawyers and judges view living customary law as non-existent, or regard living customary law as informal law that is irrelevant to state institutions.

South African judges, for example, have shown a remarkable willingness to step beyond the influence of the dominant mode of their legal education to embrace and recognise concepts of law, such as living customary law, that are located in non-western legal pluralistic theoretical frameworks. However, these judges sometimes seem to retreat into their predominantly western law and legal theoretical training and orientation when applying customary law. The result is that they bring ideas of legal centralism and positivism into the domain of customary law as well.

A classic example of this retreat is the decision of the majority in Bhe $v$ Magistrate Khayalitsha. ${ }^{31}$ In that case the Constitutional Court recognised the concept of living customary law, including its flexibility. This flexibility means that the system of law is relatively "processual", and hence less rule-

\footnotetext{
28 Leiter $2010 \mathrm{http}: / /$ doi.org/10.1017/S1352325210000121 1.

29 See generally Leiter 2010 http://doi.org/10.1017/S1352325210000121; Posner 1986-7 Case W Res L Rev 179-217; Winerib 1988 Yale LJ 949-958.

$30 \quad$ With regard to certainty, see Bennett Human Rights and African Customary Law 61; Himonga (forthcoming 2017) Acta Juridica.

31 See note 26 above.
} 
bound than the "positivist/centralist" system of law, in the sense that the application of the rules to disputes follows the repertoire of norms approach Bennett alludes to above. ${ }^{32}$. Inherently, this attribute of living customary law entails a case-by-case approach to the application of customary law in decision-making. It also entails some uncertainty in the outcomes of cases. In other words, ideally there is no precedent value in cases decided under customary law, as each case is decided entirely on its own merits. ${ }^{33}$ Interestingly, however, the majority of judges in Bhe focused on the values of certainty and uniformity associated with legal centralism and positivism in deciding whether to develop customary law in accordance with constitutional provisions. The response of the Court to the argument on this issue is quoted at length in order to underscore this point.

It was argued by one of the parties that if the Court was not in a position to develop the rules of customary law in this case, it should allow for flexibility in order to facilitate the development of the law. The majority, rejecting this argument, reasoned as follows:

The import of this [argument] was that since customary law is inherently flexible with the ability to permit compromise settlements, courts should introduce into the system those principles that the official system of succession violates. It was suggested that this could be done by using the exceptions in the implementation of the primogeniture rule which do occur in the actual administration of intestate succession as the applicable rule for customary law succession in order to avoid unfair discrimination and the violation of the dignity of the individuals affected by it. These exceptions would, according to this view, constitute the "living" customary law which should be implemented instead of official customary law. .... There is much to be said for the above approach. I consider, however, that it would be inappropriate to adopt it as the remedy in this case. What it amounts to is advocacy for a case by case development as the best option. ... The problem with development by the courts on a case by case basis is that changes will be very slow; uncertainties regarding the real rules of customary law will be prolonged and there will be different solutions for similar problems ... ${ }^{34}$

Arguably, underpinning this reasoning is the Court's support for the values of certainty and uniformity associated with the concept of law within the legal theoretical framework of centralism and positivism, as well as its affinity to the doctrine of precedent. Thus, the ghost of the training of judges in legal centralism and positivism sometimes seems to follow them when they apply

32 See Bennett Customary Law fn 6, p 3. See also Himonga (forthcoming 2017) Acta Juridica.

33 Himonga (forthcoming 2017) Acta Juridica.

34 Bhe v Magistrate, Khayelitsha (Commission for Gender Equality as Amicus Curiae); Shibi v Sithole; South African Human Rights Commission v President of the Republic of South Africa 20051 SA 580 (CC) paras 110-112. Emphasis supplied. 
customary law in decision-making. ${ }^{35}$ The training of lawyers and future judges should therefore equip them to deal not only with the dominant common-law systems of African countries but with living customary law as well.

This shift could be made by teaching law within legal theoretical frameworks that are closely associated with the concept of living customary law, the most appropriate of which is the theoretical perspective of legal pluralism.

Legal pluralism is the coexistence of distinctive legal systems in a specific social field where "laws and institutions are not subsumed within one system but have their sources in the self-regulatory activities of all the multifarious social fields present, activities which may support, complement, ignore or frustrate one another". ${ }^{36}$ Within this theoretical framework, the existence of one legal order does not depend on its recognition by other legal orders, including the legal order of the state. Living customary law fits perfectly into this theoretical framework. ${ }^{37}$

Additionally, the sociological theoretical framework that deals with the concept of living law ${ }^{38}$ could also be explored for its relevance to the teaching of law in a decolonised context. ${ }^{39}$

However, both the teaching of living customary law within the legal pluralistic (and sociological) theoretical framework and the decolonisation of law would benefit from an interdisciplinary approach to the teaching of law, to which we now turn.

\subsection{The interdisciplinary teaching of law}

An interdisciplinary approach to the study of a subject is defined as:

[A]n approach that integrates information, data, techniques, tools, perspectives, concepts, and/or theories from two or more disciplines or bodies of specialised knowledge to advance fundamental understanding or to solve problems whose solutions are beyond the scope of a single discipline. ${ }^{40}$

The National Science Foundation (NSF) in the USA has observed that the meaning of interdisciplinary studies is the subject of scholarly debates. It

35 See, however, Himonga (forthcoming 2017) Acta Juridica for the view that the statement concerned may have been limited to the exceptional circumstances of the decision in Bhe.

$36 \quad$ Griffiths $1986 \mathrm{~J}$ Legal Plur 39.

37 For detailed discussion see Himonga and Bosch 2000 SALJ 306-341.

38 See, for example, Ehrlich Fundamental Principles of the Sociology of Law.

39 For a discussion of the conceptualisation of living customary law within a sociological theoretical framework, see Himonga and Bosch 2000 SALJ 306-341.

40 The National Science Foundation in the USA (NSF) Date Unknown http://nsf.gov/od/oia/additional_resources/interdisciplinary_research/definition.jsp. 
states that interdisciplinary studies are "continually emerging, melding and transforming". ${ }^{41}$ However, we submit that the dynamism of the interdisciplinary approach alluded to in this observation offers an interesting idea for the decolonisation of legal education. This is because dynamism represents the recognition of change and transformation which is needed to meld law with other disciplines continually, in order to enhance law's potential as an instrument of social justice.

Interdisciplinary studies of law therefore offer a platform for a more profound understanding of the relationship between law in all its manifestations and regulatory practice in society. Law, as a social practice or legal science, has often closed itself off in epistemological monism. Yet, the apparent assumption underlying this monism that law can explain itself, both as theoretical corpus and social practice, cannot be established. Legal science therefore needs to open itself up to other disciplines through interdisciplinary studies. This is also essential to enhance the power of law to elucidate and transform social reality. Moreover, the problems that law is supposed to address in society often lie beyond a single discipline. Understanding the epistemological problems and sharpening the instrumentality of law in solving these problems therefore requires an integration of knowledge from different disciplines.

The teaching and study of law in a decolonised context should aim to bring together contributions from various disciplines to focus on regulatory practices embodied by law in all its manifestations. A departure from pure legal studies is envisaged, in order to focus on conceptualising, developing, problematising and proposing hypotheses common to the various disciplines and interdisciplines involved, and to question and challenge legal approaches from these perspectives. For instance, as enabling disciplines, sociology, anthropology and history can enhance the understanding, teaching and research of legal phenomena in their various contextual manifestations in Africa. This in turn can be useful for exploring alternative epistemologies, hypotheses and methods that could lead to the rediscovery of legal studies via conceptual and methodological innovations.

The proposed interdisciplinary positioning that connects legal science to other social sciences is especially important in the African context. Africa is characterised by plural legal systems, originating in colonial and, in South Africa, apartheid history, with their roots, definitions and structures in different legal traditions, frameworks and paradigms. Moreover, as the recent protests for free education and debates on transformation in some universities in South Africa have reminded the academic community, teaching and research agendas cannot remain unresponsive to social and legal plurality. Neither can they continue to be indifferent to the colonial and apartheid history and its influence on the current evolution of South Africa's

$41 \quad$ NSF Date Unknown http://nsf.gov/od/oia/additional_resources/interdisciplinary_ research/definition.jsp. 
legal traditions and social, economic and political systems. In this respect, we argue that the teaching of law should take a view of decolonisation of law that goes further than mere vernacularisation. This argument is informed by law's capacity to facilitate interdisciplinary and innovative thinking, as well as to create a platform to engage, in a critical and constructive way, with the decolonisation of law as an epistemological question beyond its political and social implications.

More specifically, interdisciplinary studies in the fields of law and anthropology, law and sociology, and law and history would introduce students and the legal profession to a way of understanding social realities that is gleaned from the lived experiences of people. This would be achieved through the multiple layers of observing, interviewing, translating, writing and interpreting (asking questions such as how to capture and understand the norms of a community, how to understand a community or ethnic group etc.), as well as through understanding of how legitimacy and authority are multi-vocal and often contested. ${ }^{42}$ Furthermore, studies in these fields would help law students and the legal profession generally to better understand issues concerning inequality, modes of oppression, and social justice. ${ }^{43}$ Studies in law and history in particular would assist students to understand the neglect of the study of living customary law in African colonial (and apartheid) history, as well as the need for a paradigm shift in the thinking about customary law as a source of law in post-colonial contexts exhibiting new constitutional mandates regarding the recognition of customary law in the legal system.

Finally, interdisciplinary studies may be useful where students are required to understand a given subject in terms of multiple traditional disciplines. ${ }^{44}$ As stated above, the connection of legal science to other social sciences is important in legal settings characterised by pluralism, and because the problems that law is supposed to address in society often lie beyond a single discipline.

In sum, the teaching of law, particularly living customary law, should incorporate an interdisciplinary approach, in order to expand the depth and quality of legal studies, and to build an academic community knowledgeable about the relevance of other disciplines for law and vice versa. The current teaching of law as a discipline does not generally equip graduates with these broad-based skills. This deficiency reduces their ability to study and research living customary law and to contribute more effectively to the development of this law as a discipline. Similar deficiencies reduce the

\footnotetext{
42 Dr Elena Moore (oral exchange - 24 May 16).

43 Dr Elena Moore (oral exchange - 24 May 16).

44 Ponnusamy and Pandurangan Hand Book on University System 13.
} 
ability of graduates to deal with customary law within the constitutional mandates of decision-making in the adjudication of disputes.

\section{Conclusion}

In conclusion, the paper has attempted to link the decolonisation of law in Africa to the teaching and survival of living customary law as a distinct legal system which regulates the lives of millions of people in Africa. This not only reflects African legal realities, but also contributes to alternative epistemologies that reveal the transformative potential of law in dealing with the social realities of Africa. In this paper we have argued that the teaching of living customary law and law generally is critical to both of these contributions. The paper has also argued that unless law teaching is redesigned to shift the legal theoretical paradigm within which law is taught and to adopt an interdisciplinary approach to the teaching of law, the project of decolonising law in African legal systems will falter if not fail to materialise. We have also attempted to show that the overall shift in the paradigm of teaching law will increase the potential of law to transform African societies and enhance social justice in a manner that is consistent with decolonisation.

\section{Bibliography}

\section{Literature}

Bennett Human Rights and African Customary Law

Bennett TW Human Rights and African Customary Law (Juta Cape Town 1999)

Bennett Customary Law

Bennett TW Customary Law in South Africa (Juta Cape Town 2004)

Chanock Law, Custom and Social Order

Chanock M Law, Custom and Social Order: The Colonial Experience in Malawi and Zambia (Cambridge University Press Cambridge 1985)

Cowen "Early Years of Aspiration to the 1920s"

Cowen D "Early Years of Aspiration to the 1920s" in Cowen D and Visser D (eds) The University of Cape Town Law Faculty: A History 1859-2004 (Siber Ink Cape Town 2004) 1-23

Ehrlich Fundamental Principles of the Sociology of Law

Ehrlich E Fundamental Principles of the Sociology of Law (Harvard University Press Cambridge Mass 1936) 
Griffiths 1986 J Legal Plur

Griffiths J "What is Legal Pluralism?" $1986 \mathrm{~J}$ Legal Plur 1-55

Himonga (forthcoming 2017) Acta Juridica

Himonga C "The Constitutional Court of Justice Moseneke and the Decolonisation of Law in South Africa: Revisiting the Relationship between Indigenous Law and Common Law" (forthcoming 2017) Acta Juridica

Himonga and Bosch 2000 SALJ

Himonga $\mathrm{C}$ and Bosch C "The Application of Customary Law under the Constitution of South Africa: Problems Solved or just Beginning?" 2000 SALJ 306-341

Himonga and Moore Reform of Customary Marriage

Himonga C and Moore E Reform of Customary Marriage, Divorce and Succession Living Customary Law and Social Realities (Juta Cape Town 2015)

Himonga 2010 Penn St Int'l L Rev

Himonga C "Goals and Objectives of Law Schools in their Primary Role of Educating Students: South Africa - The University of Cape Town School of Law Experience" 2010 Penn St Int'l L Rev 41-59

Hund 1998 ARSP

Hund $\mathrm{J}$ "Customary Law is What People Say it is - HLA Hart's Contribution to Legal Anthropology" 1998 ARSP 420-429

Kameri-Mbote, Odote and Nyamu-Musembi Ours by Right

Kameri-Mbote P, Odote C and Nyamu-Musembi C Ours by Right: Law, Politics and Realities of Community Property in Kenya (Strathmore University Press Nairobi 2013)

Odgaard and Weis Benton 1998 EJDR

Odgaard $\mathrm{R}$ and Weis Benton A "The Interplay Between Collective Rights and Obligations and Individual Rights" 1998 (10)2 EJDR 105-116

Ponnusamy and Pandurangan Hand Book on University System

Ponnusamy $\mathrm{R}$ and Pandurangan J A Hand Book on University System (Allied New Delhi 2014)

Posner 1986-7 Case W Res L Rev

Posner R "Legal Formalism, Legal Realism, and the Interpretation of Statutes and the Constitution" 1986-7 Case W Res L Rev 179-217

UCT 2015 Year in Review

University of Cape Town "Decolonising UCT" 2015 A Year in Review 22-23 
Winerib 1988 Yale LJ

Winerib E "Legal Formalism on the Immanent Rationality of Law" 1988 Yale LJ 949-958

\section{Case law}

Alexkor Ltd v Richtersveld Community 20045 SA 460 (CC)

Bhe v Magistrate, Khayelitsha (Commission for Gender Equality as Amicus Curiae); Shibi v Sithole; South African Human Rights Commission v President of the Republic of South Africa 20051 SA 580 (CC)

Ex parte Chairperson of the Constitutional Assembly: In re Certification of the Constitution of the Republic of South Africa, 199619964 SA 744 (CC)

Hotz v University of Cape Town 20172 SA 485 (SCA)

Mayelane v Ngwenyama 20134 SA 415 (CC)

SATAWU v Garvis 20131 SA 83 (CC)

\section{Legislation}

Black Administration Act 38 of 1927

Constitution of the Republic of South Africa, 1996

Recognition of Customary Marriages Act 120 of 1998

Reform of Customary Law of Succession and Regulation of Related Matters Act 11 of 2009

\section{Internet sources}

Davis 2016 http://www.groundup.org.za/article/academics-and-fallistmovement/

Davis D 2016 Academics and the Fallist Movement http://www.groundup.org.za/article/academics-and-fallist-movement/ accessed 17 November 2016

Kane, Oloka-Onyango and Tejan-Cole 2005 http://siteresources. worldbank.org/INTRANETSOCIALDEVELOPMENT/Resources/reassessin gcustomary.pdf

Kane M, Oloka-Onyango J and Tejan-Cole A 2005 Reassessing Customary Law Systems as a Vehicle for Providing Equitable Access to Justice for the Poor http://siteresources.worldbank.org/INTRANETSOCIALDEVELOP MENT/Resources/reassessingcustomary.pdf accessed 28 July 2017 
Leiter 2010 http://doi.org/10.1017/S1352325210000121

Leiter B 2010 Legal Formalism and Legal Realism: What is the Issue? http://doi.org/10.1017/S1352325210000121 accessed 24 September 2017

NSF Date Unknown http://nsf.gov/od/oia/additional_resources/ interdisciplinary_research/definition.jsp

National Science Foundation Date Unknown What is Interdisciplinary Research? http://nsf.gov/od/oia/additional_resources/interdisciplinary_ research/definition.jsp accessed 17 November 16

\section{List of Abbreviations}

$\begin{array}{ll}\text { ARSP } & \text { Archiv für Rechts-und Sozialphilosophie } \\ \text { Case W Res L Rev } & \text { Case Western Reserve Law Review } \\ \text { EJDR } & \begin{array}{l}\text { European Journal of Development Research } \\ \text { Institute for Interdisciplinary Studies of Law in } \\ \text { IISLA }\end{array} \\ \text { J Legal Plur } & \text { Journal of Legal Pluralism } \\ \text { NSF } & \text { National Science Foundation (USA) } \\ \text { Penn St Int'I L Rev } & \text { Penn State International Law Review } \\ \text { RDL } & \text { Roman-Dutch law } \\ \text { SALJ } & \text { South African Law Journal } \\ \text { U III L Rev } & \text { University of Illinois Law Review } \\ \text { UCT } & \text { University of Cape Town } \\ \text { Yale LJ } & \text { Yale Law Journal }\end{array}$

